\section{A Revista Brasileira de Psiquiatria agora tem o seu próprio site!}

Foi lançado recentemente o site da Revista Brasileira de Psiquiatria (RBP) (www.rbpbrasil.org.br) com o objetivo de melhorar a comunicação entre a revista e o leitor. O site tem uma versão em português e outra e inglês, para que seja acessado por leitores de todo o mundo. Ele contém todas as informações que o leitor e o pesquisador precisam sobre a revista e os links com a Scientific Eletronic Library Online (SciELO) para acessar os artigos das edições publicadas na internet. O site possui uma área destinada ao cadastro dos leitores para receberem a mala direta da RBP.

A grande vantagem do site da RBP é disponibilizar on-line os artigos que estão aceitos para publicação (in press) muito antes de sair na SciELO e da publicação da RBP no papel. Além disso, em breve, será possível fazer a submissão de artigos on-line de artigos para a RBP, assim como nas mais modernas revistas científicas. Desta forma, os pesquisadores vão poder divulgar os seus achados com muito mais velocidade, tornando a RBP um veículo cada vez mais eficiente para a comunicação científica e atraente para os pesquisadores.

Com um layout atual, que combina clareza e facilidade de navegação com a seriedade da revista, o novo site da RBP vai se constituir em mais um canal de comunicação e contato com os leitores. Acesse e confira!

\section{www.rbpbrasil.org.br}

Rodrigo A. Bressan

Euripedes C. Miguel

Marcos T. Mercadante

Luis Augusto Rohde

Jair J. Mari

Hermano Tavares
The Revista Brasileira de Psiquiatria has now its own website!

The website of the Revista Brasileira de Psiquiatria (RBP) (www.rbpbrasil.org.br) has been recently released, aiming to improve the communication between the journal and the reader. The site has both Portuguese and English versions, in order to enable the access by readers worldwide. It contains all information the reader and the researcher need about the journal and the links with the Scientific Electronic Library Online (SciELO) in order to reach all articles of the issues published in the internet. The site has an area for the signing up of readers who want to receive RBP's mailing.

The great advantage of the RBP's site is to publish on-line articles which are in press, much time before they are published by SciELO and in RBP's paper edition. Besides, it will be very soon possible to submit online articles for the RBP, as well as for the most modern scientific journals. Researchers will be able, therefore, to divulge their findings much faster, making RBP an increasingly efficient vehicle for the scientific communication, being attractive for researchers.

With its updated layout, which combines clarity and easy navigation to the journal's seriousness the new site of RBP will become one additional channel for the communication and contact with the readers. Access it and verify the changes!
Rodrigo A. Bressan Euripedes C. Miguel

Marcos T. Mercadante Luis Augusto Rohde Jair J. Mari Hermano Tavares 